\title{
The 22nd International Seaweed Symposium: Academia meets industry
}

\author{
Thierry Chopin ${ }^{1}$ - Alejandro Buschmann ${ }^{2}$
}

Published online: 5 August 2017

(C) Springer Science+Business Media B.V. 2017

The 22nd International Seaweed Symposium (ISS) was held in Copenhagen, Denmark, June 19-24, 2016, at the Scandic Copenhagen Hotel. The ISS is held every three years under the auspices of the International Seaweed Association (ISA). For more than six decades, the ISS has been the foremost international symposium for individuals and organizations involved with seaweed research and applications. Over the years, ISS has provided a renewed forum for scientists, technologists, business people, and resource managers to present their latest research results, exchange ideas and network to develop synergies for strengthening this important bioresource sector.

This year, 451 participants from 49 countries presented and discussed many aspects focusing on the theme of this year's edition "Academia meets industry." This theme recognized the fact that academic research plays a fundamental role in the development of the seaweed industry at different levels (cultivation, harvesting, processing, commercialization, protection, management, etc.) and much has to be gained by working together.

The program was a rich learning experience and provided opportunities for stimulating discussions. It was developed by the National Organizing Committee (NOC), with the help of the members of the International Seaweed Association Council (ISAC). We would like to thank, in particular, Susan Holdt (chair of the NOC), Annette Bruhn and Henrik

Thierry Chopin

tchopin@unbsj.ca

1 Canadian Integrated Multi-Trophic Aquaculture Network, University of New Brunswick, 100 Tucker Park Street, Saint John, NB E2L 4L5, Canada

2 Centro i-mar \& CeBiB, Universidad de Los Lagos, Camino Chinquihue km 6, Puerto Montt, Chile
Jarlbaek (secretaries), Mikael Eriksen (treasurer), Charlotte Jacobsen, Ole Mouritsen, Hans Porse and Peter Salling.

There were six excellent plenary presentations, highly diverse and delivered in very different and captivating styles:

(1) Rocky de Nys (Australia) took the audience through his integrated multi-trophic aquaculture experience with "The integrated culture of seaweeds in waste watersenvironmental drivers and product options",

(2) Brian Rudolph and Hans Porse (Denmark) covered "The seaweed hydrocolloid industry: 2016 updates, needs and outlook",

(3) Yimin Qin (China) talked about "Research and applications of bioactive seaweed substances-a Brightmoon perspective",

(4) Ester Serrao (Portugal) offered her perspectives on "Shifting genetic baselines in marine forests",

(5) Chef René Redzepi (Denmark) was interviewed by Ole Mouritsen to talk about "The use of seaweeds in higher gastronomy", and

(6) Catriona Hurd (Australia) illustrated the impacts of water motion through her in-depth lecture "Shaken and stirred: water motion regulates seaweed resource acquisition and productivity".

Forty sessions with 214 oral presentations, and 2 sessions with 130 posters covered a suite of topical and varied subjects in which seaweeds play crucial roles: cultivation - land-based systems; cultivation - reproductive biology, breeding, and genetics; cultivation - design and surfaces; cultivation-optimizing temperate seaweeds; cultivation-tropical species; cultivation - stimulation of growth; phycocolloid processing; bioactives-fucoidans; bioactives - antioxidants; bioactives - non-food applications; seaweeds for food, feed and pharma products; seaweeds as food and feed-nutrition/ 
taste/texture; biofuels; ecology—alien, invasive and bloom forming species; ecology—ecophysiology; ecology—diversity, biogeography and productivity; history; seaweed valorization; risk assessment; integrated multi-trophic aquaculture and biomitigation; seaweed farming - the next agriculture; seaweed cell wall and associated microbes; challenges and novel enzymes; molecular biology-systematics; molecular biology - stress and defense; socio-economic impacts of seaweed farming; seaweed management and harvesting; ecosystem services; biorefinery, processing and novel enzymes; climate and ecology; and the future of seaweed cultivation.

As interesting and uplifting as it is to see a renewed interest in seaweeds, their cultivation and their use in very diverse applications, one sometimes had to be cautious and filter the information received, as there was a certain penchant for Photoshop illustrations in some presentations, or absence of support for some information obviously found on the Internet, and announcements of grandiose plans not very rooted in the reality of experimental data or pilot-scale trials. This is when it is so important for academia to meet with the industry, to get a dose of reality, as provided for by the successive ISS for decades. Moreover, with the plethora of new algal/seaweed conferences sprouting every year, it becomes difficult to generate new information in the lapse of a few months, and the impression of "déjà vu" with some presentations was obvious. It is clear that, as these conferences multiply and become more and more expensive to attend, people will scrutinize more closely what potential knowledge and technology/information transfer they will gain from the different events before choosing which one(s) to attend. The release of strong and carefully articulated programs in due time is becoming more and more important to help potential participants in their selection (associated with the choice of attractive destinations and affordable registration packages).

It was sometimes difficult to sit and listen to some presenters, who, obviously, did not have the ecological, physiological or biochemical knowledge that could have simplified their investigations and explained some of their apparently confusing results. It was interesting to note that some of those who contributed to that very knowledge, in recent decades, were in the audience, allowing for fruitful discussions during and after sessions, which certainly help in scientific and technological progress and development. Knowledge, experience, and wisdom take time to acquire, often after attending many ISS, hence, with a certain age and when one's hair or beard is turning gray or white!

Throughout the week, a number of exhibitors displayed and sold food, seasonings, beverages, jewelries made of seaweeds, and table clothes and oven mittens with seaweed patterns.

On Tuesday, June 21, participants attended a reception at the Copenhagen City Hall for a double treat: they were served the renowned City Hall sweet pancakes by representatives of the city council; they were given a rare tour of one wing of the City Hall, in which the walls and ceilings of offices were painted, in 1902-1903, by Jens Møller-Jensen (1869-1948) and his wife Sigrid Vold (1875-1968), with representations of seaweeds and other marine scenes in an interesting Art Deco fresco style. The artists took some license in their depiction of the seaweeds; however, several species can be easily recognized.

The mid-symposium excursions, on Wednesday, June 22, were an opportunity to learn about the history and culture of Denmark, see some Danish algal endeavors and renew contacts with colleagues, in a relaxed atmosphere.

On Thursday, June 23, the symposium dinner took place at the Langelinie Pavillonen, situated just a few hundred meters from the famous Little Mermaid and overlooking Copenhagen Harbor.

On Sunday, June 19, before the 22nd ISS really started, the ISAC had its triennial face to face meeting. ISAC is the governing body of the ISA with 12 elected members conducting business electronically in between each ISS. Three members had their mandate expiring with the 22nd ISS: Rhodora Azanza (the Philippines), Robert Anderson (South Africa) and Thierry Chopin (Canada). To all three, we express our gratitude for their commitment to the ISA. Three new members joined the ISAC: Susan Holdt (Denmark), Flower Msuya (Tanzania), and Norishige Yotsukura (Japan). For the period 2016-2019, Stefan Kraan (Ireland) becomes president, Daniel Robledo (Mexico) becomes vice-president, Gonzalo Soriano (Argentina) remains treasurer, Susan Holdt becomes secretary general, and Alejandro Buschmann (Chile) becomes past-president.

Thierry Chopin was involved with the ISAC for 12 years (vice-president 2004-2007; president 2007-2010; pastpresident 2010-2013; secretary general 2010-2016). During that time, he focused his actions at seven levels:

(1) Evolve the ISA from a mainly phycocolloid-dominated organization into a much more diversified association reflecting new trends in the evolution of seaweed cultivation, harvesting, processing and applications (human food, animal feed, bioactives, pharmaceuticals, nutritionals, integrated multi-trophic aquaculture, ecosystem services, integrated sequential biorefinery approach within a circular economy, etc.), in research techniques and best practices, and in management tools and socioeconomic policies to safeguard the future of the global seaweed sector.

(2) Reinforce female representation on the Council; with the departure of Rhodora Azanza, it was important to keep female representation on the ISAC and for the 2016 elections there were nine candidates (six females and three males): two females and one male were elected. It is hoped that female representation on the ISAC will continue to grow in the future.

(3) Rationalize the operating budget of the ISA, which grew, over 12 years, from US $\$ 45,000$ to US $\$ 146,000$, allowing survival beyond the 3-year cycle from ISS to ISS, and the 
opportunity to start planning some strategies benefitting the membership.

(4) Use this more stable budget to be able to invest in the long-term support of students, the "new blood" necessary for the sustainability of the ISA. The generous amount given in 1989 by the organizers of the 13th ISS at the University of British Columbia (Vancouver, Canada) is close to being spent, because the capital was disbursed as awards over the years instead of being invested with the interest being used for the awards. The ISAC has now embarked in the development of an endowment fund, which will generate higher interests, used as the basis to create new student awards, called the Maxwell S. Doty Awards. Max Doty (1916-1996) was both an accomplished scientist and a visionary seaweed farmer. He was elected to the ISAC in 1971 and remained one of its members until 1992; on his retirement from the ISAC he was made an Honorary Life Member of the ISA. At the time of the ISS in Copenhagen, the ISA had pledged US\$25,000 and Gonzalo Soriano had already secured US $\$ 33,000$ from several generous industry and individual benefactors. If you want to make a donation to the Maxwell S. Doty Endowment Fund, please, contact our treasurer.

(5) Stabilize the production and reduce the publishing time of the ISS Proceedings, which are now published by Springer, under the efficient and competent editing of Michael Borowitzka, the editor-in-chief of the Journal of Applied Phycology, his editorial board and a group of guest editors for each ISS, all improving the reviewing process and its quality.

(6) Develop an excellent and reliable relationship with Alexandrine Cheronet, the senior publishing editor in Environmental Sciences at Springer. This resulted in a special deal for ISA members in 2013. People attending an ISS become de facto members of the ISA for the next three consecutive years, until the next ISS; during that period of time, they have free online access to the Journal of Applied Phycology, in which the ISS Proceedings are published as special issues. The deal is effective now for the participants of the 22nd ISS between 2016 and 2019. People attending the 23rd ISS, in Jeju, the Republic of Korea, will be offered the same valuable membership benefit between 2019 and 2021 .

(7) Modernize the ISA code, the bylaws of the ISA, which had not been revised since 2007. This document was removed from a larger one, containing the Manual of Operations of the ISA, and has been posted on the ISA website (http://www.isaseaweed.org/code.php). The Manual of Operations still has to be completely recast to reflect modern ways of running the ISS. Surgery in 2015 delayed these efforts, which should certainly be pursued by the ISAC and the successive NOCs, as it should remain an adaptive and dynamic document reflecting local and changing organizing conditions for ISS and the evolution in running conferences and events.

At the closing ceremony, on Friday, June 24, the University of British Columbia (Vancouver, Canada) awards were given to the best three student oral presentations, and the National Organizing Committee of the 22nd ISS (Copenhagen, Denmark) gave three awards for the best poster pitches. The winners received certificates, their award cheques, and a gift certificate of $€ 200$ from Springer.

\section{University of British Columbia Student Oral Presentation Awards}

1st Prize: Stephens T, Hepburn C. Macrocystis pyrifera prioritizes tissue maintenance in response to nitrogen fertilization.

2nd Prize: Melton JT, Lopez-Bautista JM. Organellar genomes of Ulva spp. and phylogenomics of the "Core Chlorophyta."

3rd Prize: Im SH, Kim GH, Klochkova T. Innate immunity and constitutional defense mechanism of Pyropia tenera against viral infection.

\section{National Organizing Committee of the 22nd ISS Poster Pitch Awards}

1st Prize: Salmeán AA, Duffieux D, Harholt J, Qin F, Gurven M, Willats WGT, Hervé C. Mixed-linkage glucan, MLG, $(1 \rightarrow 3),(1 \rightarrow 4)-\beta$-glucan.

2nd Prize: Wijesekara I, Lang M, Gemin M-P, Burlot AS, Bedoux G, Bourgougnon N. Different extraction procedures and analysis of protein from Ulva sp. in Brittany, France.

3rd Prize: Aldridge J, Capuzzo E, Forster R, van der Molen J. Investigating potential effects of hypothetical large-scale macroalgae farms.

The International Seaweed Association would like to thank the two committees of judges, who were in charge of the very difficult task of evaluating these well-prepared student oral presentations and poster pitches.

All in all, the 22nd ISS was a fine example of Danish "Hygge" (the art of creating a good and warm social atmosphere/coziness and enjoying good things) during a week that enabled the coverage of the whole spectrum of research and development and commercialization, to encourage the advancement of a sustainable and innovative seaweed sector around the world. 
Let us meet again during the 23rd ISS, on Jeju Island, in the Republic of Korea, on April-May 2019. The very capable NOC is already hard at work and, given Korea's long history of seaweed cultivation, is proposing an exciting symposium, whose theme will be "Seaweeds: from tradition to innovation.” 